\title{
Fluidized Bed Combustion and Gasification of Fossil and Renewable Slurry Fuels
}

\author{
Francesco Miccio ${ }^{1, *(0)}$, Federica Raganati ${ }^{2}{ }^{(}$, Paola Ammendola ${ }^{2}\left(\mathbb{D}\right.$, Farouk Okasha $^{3}$ and Michele Miccio ${ }^{4}$ \\ 1 Istituto di Scienza e Tecnologia dei Materiali Ceramici (ISTEC)-CNR, Via Granarolo 63, 40069 Faenza, Italy \\ 2 Istituto di Scienze e Tecnologie per l'Energia e la Mobilità Sostenibili (STEMS), Via G. Marconi, \\ 80125 Napoli, Italy; federica.raganati@stems.cnr.it (F.R.); paola.ammendola@stems.cnr.it (P.A.) \\ 3 Department of Mechanical Power Engineering, Faculty of Engineering, University of Mansoura, \\ Republic Street, Mansoura 35516, Egypt; engfac@mans.edu.eg \\ 4 Dipartimento Ingegneria Industriale (DIIN), Università degli Studi di Salerno, Via Giovanni Paolo II 132, \\ 84084 Fisciano, Italy; mmiccio@unisa.it \\ * Correspondence: francesco.miccio@cnr.it; Tel.: +39-0546-699774
}

Citation: Miccio, F.; Raganati, F.; Ammendola, P.; Okasha, F.; Miccio, M. Fluidized Bed Combustion and Gasification of Fossil and Renewable Slurry Fuels. Energies 2021, 14, 7766 https://doi.org/10.3390/en14227766

Academic Editor: Kalyan Annamalai

Received: 3 October 2021

Accepted: 16 November 2021

Published: 19 November 2021

Publisher's Note: MDPI stays neutral with regard to jurisdictional claims in published maps and institutional affiliations.

Copyright: (c) 2021 by the authors. Licensee MDPI, Basel, Switzerland. This article is an open access article distributed under the terms and conditions of the Creative Commons Attribution (CC BY) license (https:// creativecommons.org/licenses/by/ $4.0 /)$.

\begin{abstract}
This article provides a comprehensive review of the state of the art and more recent developments of the thermochemical treatments of slurry fuels in fluidized beds (FB). The review focuses on FB combustion and gasification of slurry fuels based on coal, biomass, sludge, and wastes from industry, agriculture, and the civil sector. The investigations at research and industrial levels over the last decades are presented and discussed, highlighting the adopted technological solutions, the results in terms of feasibility and efficiency, and the perspectives of future development. The different behavior between bubbling and circulating beds was addressed, in particular the optimal choice depending on the process (combustion/gasification/pyrolysis) and fuel properties (e.g., water content). Fundamental studies on interactions between the slurry fuels and the hot bed materials are also reviewed. The cumulative trend of reviewed investigations over the last decades depicts the abandonment of coal-based mixtures used in large plants, and the growing interest in the use of biomass-based slurries for small size application. In this respect, the shift from coal to biomass opens new challenges because of the different properties of biomass (density, fibrous structure, spontaneous degradation, hydrophilic behavior, etc.). Biomass-based slurries circumvent problems posed by using solid dry biomass, particularly in handling, storing, and feeding. Although slurry fuels represent a narrow sector, the results of the research investigations and the experience gained with coal can be exploited to contribute to the achievement of a circular approach based on renewable resources in the near future.
\end{abstract}

Keywords: fluidized bed; slurry fuel; combustion; gasification

\section{Introduction}

Fluidized bed (FB) technology has been widely used in the energy sector and industrial chemistry for accomplishing heterogeneous processes for converting various feedstock into chemicals or heat. FB technology is very flexible towards the properties of the materials to be processed (i.e., feedstock heating value, moisture, particle size and density, sulfur content, etc.) [1] and possesses superior performance in terms of heat [2] and mass transfer $[3,4]$. In particular, combustion and gasification have been developed and carried out in the last five decades at small and medium size using solid fuels in the form of coarse powder, granules, chips, and pellet both of fossil and renewable origin $[5,6]$. The most relevant features of FB with respect to other technologies (i.e., fixed beds, moved beds, and rotating furnaces) $[7,8]$ are the temperature homogeneity, the elevated heat transfer rate, the good mixing of the solid particles, and the possibility of accomplishing further sub-processes, e.g., particle drying, heterogeneous catalysis, and $\mathrm{SO}_{2} / \mathrm{CO}_{2}$ capture [9-11]. 
FB reactors can be used in different configurations, such as bubbling (BFB) and circulating (CFB) fluidized beds [12]. In a BFB, the bed media is made of particles typically $0.5-1.0 \mathrm{~mm}$ in size, Group B of the Geldart classification [2] and is fluidized from the bottom with a velocity varying in a range from 1 to $3 \mathrm{~m} / \mathrm{s}$ [3]. Under these conditions, the bed $\backslash$ material is fully fluidized and behaves like a boiling liquid [13]. The fluidization state is maintained by a gas-bubble emulsion which continuously agitates the solid phase, enabling good mass and heat transfer between the solid and gas phase. In the upper part of the reactor, i.e., the freeboard, only the gas phase is present, as the bed material does not normally get carried this high. Some of the gas-phase reactions take place here, even though the main stages of thermochemical conversion occur within or just above the fluidized bed [14]. In CFBs, the bed material, typically of a smaller diameter (e.g., 0.2-0.5 mm) than in BFBs, is fluidized with superficial velocities up to three to five times $(5-10 \mathrm{~m} / \mathrm{s})$ larger than in BFBs [3]. As a consequence, char and bed particles become entrained in the gas stream, thus increasing the amount of solids in the freeboard. A downstream unit is, therefore, required to separate (e.g., using a cyclone) and recirculate these particles. Recycling the solids has the advantage of increasing the particle residence time, thus improving the carbon conversion efficiency and reaction rates $[15,16]$. The pressurized variant of FB technology (PFB) has been also developed over the last decades for the obvious advantages in plant capacity and compactness, as well as the increase of electrical efficiency when flue gases are expanded in a turbine [17].

Coal-water mixtures (CWM) have been proposed as substitute of heavy oil in the decades between 1970 and 1990 for the feeding of conventional power plants. CWMs are composed of water, coal, and additives, giving rise to an oil-like liquid. In their preparation, the coal particle diameter is between 10 and $100 \mu \mathrm{m}$, upon milling of the parent coal [18], and the water content is around 30\% wt. [19]. CWMs drastically limit the hazards of pulverized coal storage/handling and the logistic costs, both CAPEX and OPEX, contributing to reducing the environmental impact of coal [20]. Different from coal/water mixtures, attaining a high solids content but also high viscosity, Antonini and Francois [21] first pointed out that if the water is added to produce an aqueous foam the resulting coal/water/air mixture will be more stable, easy to prepare, and readily pumpable because of the lubricant effect of surfactants. Both CWMs and coal foams were the object of investigation for FB combustion in the last decades [22].

In parallel, the combustion in fluidized beds of unconventional liquid-like fuels for heath and power generation or their conversion into more valuable streams via gasification were undertaken at a research and industrial level in response to requests for exploiting locally available resources or as an alternative to landfill disposal in the logic of a circular economy.

Fluidized bed reactors have distinctive features that confer them the superiority to treat slurries, sludge, or other waste (e.g., industrial, agricultural, and animal waste) in dried form $[23,24]$ or with high water content $[25,26]$. First, the high turbulent motion of particles disperses the fed wet materials throughout the bed. Second the high thermal inertia of the bed enables water evaporation while maintaining good temperature control. Moreover, a fluidized bed reactor can be easily supported with a secondary fuel when wastes with high water content and low heating value are processed. A fluidized bed can handle or co-fire fuels with different phases: solid, liquid, or even gaseous fuels [27,28]. Alternatively, an entrained flow gasifier and conventional burner can handle only wellpre-treated coal or biomass slurry. In this respect the fuel should be well-pulverized, and the slurry should have good atomization characteristics [29,30]. On the other side, sludge needs to be dried and briquetted before being processed in fixed bed reactors [31]. Only rotary kiln reactors may process wet sludge with similar efficiency as FB, but a lower, even null, heat transfer rate [32]. One of the most relevant drawbacks of FB processes is the occurrence of agglomeration phenomena due to bed sintering induced by alkali content in fuels, in particular wastes and residues, leading to plant malfunction and maintenance intervention [33]. In this respect, using suitable and cheap alternative materials to silica 
sand would be effective for inhibition of agglomeration phenomena [34,35]. Comminution phenomena are also likely to occur in FB plants and should be considered as possible causes of loss in efficiency [36]. This aspect is particularly serious in the case of less reactive fuels and the gasification process.

The possibility of using uncommon feedstocks contributed to expanding the application of FB technology, thanks to FB enhanced flexibility with respect to the nature and properties of the fuel. Thus, they are interesting alternatives to substitute granular fossil and renewable fuels. For instance by-products of the mining industry [37] and sludge of agro-industrial processes [38] can be turned out into mixtures with auxiliary fuels, to be directly burnt without additional costs of drying or disposal.

The advantages of using liquid-like fuels in pressurized operation are evident when considering the complex technology required to handle and to feed granular or pulverized coal to pressurized plants [22]. So far, the use of liquid-like fuels is much easier and safer, only requiring conventional equipment, such as tanks, pipelines, and pumps.

Keeping out of this review fuels derived from liquid hydrocarbons or their suspensions in water [39], the unconventional liquid-like fuels that are considered hereinafter may be classified according to the following scheme:

- Coal/coke Water Mixture (CWM)

- Coal Water Paste (CWP)

- Coal-oil Slurry (COS)

- Coal-water Foam (C-WAM)

- Waste Derived Mixture (WASMIX)

Results of research and exploitation at laboratory, pilot, and industrial scales are reviewed and discussed for the sake of giving recommendations for combustion, gasification/pyrolysis, and other related issues. In particular, the present paper provides a comprehensive review of the state of the art and more recent developments of the thermochemical treatments of slurry fuels by means of FB combustion and gasification. Therefore, it can be helpful for all readers, from both academia and also industry, who are interested in the available and efficient processes/technologies for exploiting slurry fuels and in the related technical issues/challenges. In addition to this, this review is also intended to give practical insights for the orientation of the scientific and technical community during the current transition from fossil fuels to renewable energy systems.

\section{Coal Water Mixture (CWM)}

The utilization of coal-water mixtures as a fuel in FBC was proposed since the 1980s. Table 1 reports the chronology of studies concerning the feeding of ordinary and specialpurpose CWM in FB combustors of various sizes and geometries, under atmospheric and pressurized conditions. In general, submerged feeding was adopted.

\subsection{Combustion Efficiency}

The pioneering work of La Nauze et al. [40] was indeed devoted to investigating the incineration of coal washery liquid wastes. They demonstrated the ability of FB combustion to efficiently burn the waste without recourse to auxiliary fuel and with high recovery of heat. Trivett et al. [41,42] developed and tested a small-scale $(30 \mathrm{~kW})$ combustor that was intended as a replacement for the oil furnace in domestic heating and in light industrial application. Massimilla's group $[43,44]$ keenly investigated the effect of submerged CWM feeding in an atmospheric pilot plant by means of an air-assisted fuel injector. They speculated and verified the carbon load in the bed under both isolated particle and sand adhered phases, whose extent was determined by the injection conditions.

Pressurized combustion was investigated by Roberts et al. [37] and Hoy et al. [45] in pilot plants operated at up to $2 \mathrm{MPa}$. 
Table 1. Investigations on coal-based mixtures in fluidized bed.

\begin{tabular}{|c|c|c|c|c|c|}
\hline Internal Size (mm) & Slurry Fuel & Feeding Point & Pressure & Process & Ref. \\
\hline $2600 \times 1600^{2}$ & CWM & overbed & atmospheric & combustion & [40] \\
\hline $250^{1}$ & CWM & overbed & atmospheric & combustion & {$[41,42]$} \\
\hline $600^{1}$ & CWM & submerged & $0.6 \mathrm{MPa}$ & combustion & {$[37,45]$} \\
\hline \multicolumn{6}{|l|}{$80^{1}$} \\
\hline $250^{2}$ & CWM & overbed & atmospheric & combustion & [46] \\
\hline \multicolumn{6}{|l|}{$500^{2}$} \\
\hline $450^{1}$ & CWM & underbed & atmospheric & combustion & [47] \\
\hline $370^{1}$ & CWM & submerged & atmospheric & combustion & {$[43,44]$} \\
\hline $300^{2}$ & CWM & submerged & $2 \mathrm{MPa}$ & combustion & [45] \\
\hline $200^{1}$ & CWM & submerged & atmospheric & combustion & [48] \\
\hline $140^{1}$ & CWM & submerged & atmospheric & pyrolysis & [49] \\
\hline $5640^{1}$ & CWP & n.a. & $1.2 \mathrm{MPa}$ & combustion & [50] \\
\hline $51^{1}$ & cos & submerged & atmospheric & combustion & [51] \\
\hline $600^{1}$ & C-WAM & submerged & atmospheric & combustion & {$[52]$} \\
\hline $1130^{1}$ & C-WAM & submerged & pressurized & combustion & [52] \\
\hline $140^{1}$ & C-WAM & submerged & atmospheric & pyrolysis & [52] \\
\hline
\end{tabular}

${ }^{1}$ Circular geometry; ${ }^{2}$ Square/rectangular geometry.

During the combustion of CWM in a fluidized bed, comparatively higher combustion efficiencies were obtained by many researchers with respect to dry coal feed. The excess air ratio was kept in the typical range of $\mathrm{FB}$ combustion for coal (1.1-1.3), with $\mathrm{O}_{2}$ concentration in flue gases up to $5 \% \mathrm{vol}$ [43]. The combustion efficiencies reported by several investigators were in the range $0.85-0.98$ under atmospheric conditions [44,46] and exceeded 0.99 for pressurized FB combustion [45]. The comparison with dry coal feeding under the same operating conditions turns out favorable for CWM that exhibit an appreciable gain of efficiency ( 5 to 10 percentage points) $[46,48]$. The improved performance of CWM is primarily attributed to the formation of rather strong char agglomerates upon interaction of wet feed with the hot bed particles, which provide a large reaction surface area and reduce elutriation of fines from the bed.

\subsection{Fuel Dispersion in the Bed}

The mechanism of CWM dispersion in the bed and the interactions between droplets and bed particles were keenly investigated under inert conditions both theoretically [53] and experimentally [49]. Three different and coexisting ways were evidenced, by which fixed carbon is made available from CWM within the bed: they are bed particle-carbon aggregates, carbon-spotted bed particles and flying carbon fines (Figure 1). The formation rates and the yields of the three carbon fractions were estimated by a mathematical model based on the establishment of a flare region at the combustor wall where the injected slurry interacts with hot bed particles. For a fixed design of the injection device, the distribution in three fractions is dependent on the coal rank, gas dispersion velocity at the nozzle and mass ratio between gas and slurry flow rates [53]. The fate of the three carbon fractions is also reported in Figure 1; in particular, they are converted in a gas product (i.e., $\mathrm{CO}_{2}$ ), whereas the fines may be partially elutriated. The model validation was obtained by experimental investigation in a dedicated plant at a semi-pilot-scale, providing rather good agreement between predictions and experimental results [49]. It is remarkable that utilization of bituminous coal with respect to coke or hard coal is to be preferred because of its high tendency to formation of aggregates with beneficial effects on the combustion mechanism. Miccio et al. [49] reported fractions in the ranges $0.45-0.70,0.25-0.50$, and $0.05-0.18$ for A-, $\mathrm{S}-$, and F-phases, respectively. It is worth noting that the error on fixed carbon balance was higher (about 20\%) for CWM with an appreciable content of volatiles, whilst it was lower than $10 \%$ in the case of CWM based on petroleum-coke. 

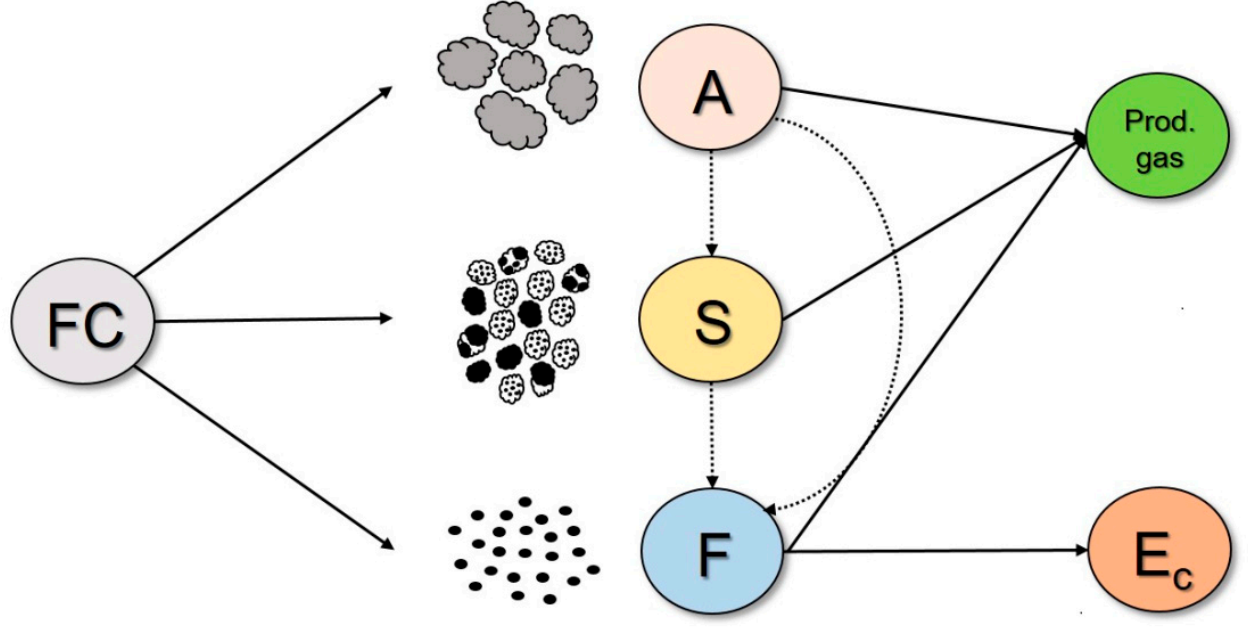

Figure 1. Carbon fractions present in the bed and their fate during the thermochemical conversion process: (FC) fixed carbon; (A) bed particle-carbon aggregates; (S) carbon-spotted bed particles; (F) flying carbon fines; (Ec) elutriated carbon.

The described mechanism of phase formation applies only to the case of submerged feeding that is more complex but also more efficient for retaining and spreading combustible matter in the bed. In this configuration (under-bed), a dilute region establishes in the dense bed close to the fuel injection port with periodic detachment of bubbles containing slurry vapors and the dispersion gas [53]. This behavior is similar to that of a fluidized bed with lateral gas jets [54].

\section{Coal-Water Pastes (CWP) and Coal Oils Slurries (COS)}

Coal-water pastes (CWP) are produced from coarse coal particles with a size up to a few millimeters, sometimes with a bimodal distribution [55]. Contrary to the case of CWM conceived for spray burners, sophisticated rheological properties are not required for fluidized bed feeding of CWPs, provided that they have enough stability during storage and transport. Overall, they behave as a non-Newtonian Herschel-Bulkley fluid, whose rheology can be tuned by changing water content, particle size distribution, and additives (e.g., the latter for desulphurization) [55].

CWP were used to fire utility-scale PFB boilers that were developed by ABB Carbon [50] as compact modules for electricity generation with a combined cycle. The PFBC boiler has the characteristic of integrating into a single component, the pressure vessel, the fluid bed for combustion and desulfurization, heat exchangers for steam production, and the multi-cyclone system for flue gas de-dusting. This technological solution has generally favored coal supply in the form of a water paste, which is lower than $30 \%$ wt. in $\mathrm{H}_{2} \mathrm{O}$, pumpable, and versatile in use. The nominal power of a single module P200 was $200 \mathrm{MW}_{\mathrm{t}}$. at a pressure of 12 bar. A number of plants were commissioned and operate in the world and more than 70,000 h of operation have been accumulated on P200 modules, demonstrating the reliability and efficiency of this PFB technology [56]. The CWP combustion in PFB commercial units yielded a combustion efficiency up to $99.7 \%$, a desulfurization efficiency of the order of $90 \%$ and an overall combined cycle efficiency close to $40 \%$.

Coal-oil-water slurries (COS) are suspensions where an appreciable fraction of hydrocarbons is present, with beneficial effects on heating value, kinetic properties (e.g., ignition delay), and rheology [57]. Purposely prepared coal-oil (50/50 wt.) and coal-oil-water $(47 / 12 / 40 \mathrm{wt}$.) slurries were gasified in a laboratory-scale FB plant in a steam-oxygen and $\mathrm{CO}_{2}$-oxygen atmosphere [51]. Typical compositions of COS are reported in Table 2. In both cases, rapeseed oil was used for slurry preparation. Polish coal and German lignite were alternatively used in form of powder, with a size below $315 \mu \mathrm{m}$. The main differences between the two used coals were the hydrophilic/hydrophobic character and the content of fixed carbon. The gasification at temperature between 800 and $900{ }^{\circ} \mathrm{C}$ gave rise to 
producer gas with different characteristics, depending on parent fuel, water content and gasifying agent. Cold gas efficiency was highest (up to 61\%) for coal-oil slurry based on German lignite in both atmospheres, owing to the higher reactivity of its char. The highest heating value of the producer gas was obtained for coal-oil slurry based on German lignite, achieving value up to $18 \mathrm{MJ} / \mathrm{m}^{3}$ ( $\mathrm{N}_{2}$ free). However, tar content is very high for coal-oil slurries with respect to coal-oil-water slurries in inert (silica sand) bed. The author also reported that formation of stable coal-oil-water slurries requires irradiation by ultrasound and addition of an emulsifier ( $1 \%$ wt.) Moreover, long term stability of such slurries is weaker than the stability of coal-oil slurries.

Table 2. Typical composition data for COS [51,58].

\begin{tabular}{cccc}
\hline Components (\% wt.) & $\begin{array}{c}\text { German Coal-Oil Slurry } \\
\mathbf{( 5 0 / 5 0 )}\end{array}$ & $\begin{array}{c}\text { Polish Coal-Oil Slurry } \\
\mathbf{( 5 0 / 5 0 )}\end{array}$ & $\begin{array}{c}\text { Polish Coal-Oil-Water Slurry } \\
\mathbf{( 4 7 / 4 0 / 1 2 )}\end{array}$ \\
\hline Water & 4.50 & 3.85 & 43.37 \\
Ash & 1.90 & 4.33 & 4.07 \\
Volatiles & 71.7 & 61.7 & 33.9 \\
Fixed carbon & 21.8 & 30.1 & 18.6 \\
C (dry) & 70.94 & 75.98 & 73.42 \\
H (dry) & 8.18 & 7.88 & 5.76 \\
O (dry) & 18.46 & 10.86 & 12.42 \\
N (dry) & 0.347 & 0.552 & 0.880 \\
S (dry) & 0.084 & 0.220 & 0.326 \\
Cl (dry) & $<0.1$ & $<0.4$ & $<0.4$ \\
LHV, MJ/kg & 29.8 & 32.3 & 16.8 \\
\hline
\end{tabular}

\section{Coal-Water Foam (C-WAM)}

A research project dedicated to FB combustion of C-WAM was funded by the European Commission under the JOULE Programme from 1990 to 1994. The project provided useful insights into the utilization of C-WAM at different plant scales, as well as atmospheric and pressurized conditions. Three main experimental facilities were employed [52]: a pilot-scale, $1200 \mathrm{~mm}$ ID, pressurized combustor (FLAP) at ENEL/CRT (Livorno, I); a pilotscale, $600 \mathrm{~mm}$ ID, atmospheric combustor at CERCHAR (Mazingarbe, F); and a semi-pilot facility at CNR (Napoli, I). Both the ENEL and CERCHAR combustors were fired under steady-state conditions in a number of tests that were purposely planned without sorbent addition. The ENEL plant was operated at a pressure of about $0.3 \mathrm{MPa}$ gauge. The CNR facility was employed in hot tests that were aimed at determining the bed dispersion characteristics of the foam and, therefore, was run batch-wise without combustion. In all three cases C-WAM was smoothly fed into the bed by horizontal injectors of similar geometry and submerged condition.

\subsection{Combustion Behavior}

On the basis of test runs at CERCHAR and ENEL, C-WAM combustion turned out feasible at atmospheric and moderately high pressure (0.3 MPa gauge). At atmospheric pressure, successful burning was achieved by operating air staging. The excess air ratio was up to 1.3. Under pressurized conditions, reliable operation was obtained without air staging and ash recycling. The combustion efficiency was up to $92 \%$ [52], representing a quite acceptable value, considering the absence of elutriated fines recycles.

The temperature profiles along the vertical axis proved that during the tests with dry coal the freeboard was cooler than in tests with C-WAM that exhibited a freeboard temperature increase up to $30^{\circ} \mathrm{C}$ [52]. This finding appears rather surprising as the overbed feeding adopted for dry coal usually leads to a larger heat release in the freeboard. Therefore, the higher temperatures measured along the freeboard demonstrate that, combustion of C-WAM is partially shifted from bed to freeboard due to carbon fines elutriation. Hence, the freeboard should be designed to be an effective post-combustor of unburned particles 
and gases, which are released from the bed especially when this latter one is over-loaded of fines.

\subsection{Fuel Dispersion in the Bed}

C-WAM has the same general behavior as CWMs, as far as the formation of carbon phases is concerned. The experiments carried out with a semi-pilot facility demonstrated that all three phases are formed when injecting C-WAM into the bed. Bed sampling proved that sand turned out gray and the surface of particles appeared spotted by tiny carbon deposits. This observation was confirmed by chemical analysis: the bed fraction containing most of sand, i.e., the size fraction from 0.60 to $0.85 \mathrm{~mm}$, had a carbon content one to two orders of magnitude larger than that found in combustion tests with dry feed of same coal, where formation of spotted sand is unlikely.

Compared to standard CWM, C-WAM has a lower tendency to form aggregates, with about $10 \%$ of fixed carbon converted to A-phase [52]. Both the latter findings and the high formation rate of fines are in the direction of making C-WAMs more difficult to burn in bubbling FBC. Once formed, fines have a low residence time in the bed as they percolate through the interstices of the dense phase and are rapidly entrained by gases leaving the bed. As a consequence, they can reach the exit of the combustor with unsatisfactory conversion. Formation rate of an S-phase, however, is high: this plays a role in an opposite direction as carbon deposited on bed particles cannot leave the bed until it is burned or abraded. It is likely that the violent expansion of the C-WAM stream issuing from the nozzle creates a three-phase zone in the bed and this region contains gas (fluidizing air and propelling air from C-WAM, volatiles, and water vapor), liquid water and solids (coal and sand). Fine carbon particles escape from the bulk of C-WAM and hit bed particles inside and, more likely, at the boundaries of this region, forming an S-phase.

\section{Waste-Derived Mixtures (WASMIX)}

Waste derived mixtures (WASMIX) include liquid refuse-streams, such as suspension, slurry, and sludge, etc., that are produced by civil and industrial activities. They may have variable water content, depending on the season. WASMIXs are also subjected to changes in their properties during storage and handling, loss of odors in the atmosphere, as well biological degradation. Their beneficiation or incineration in conventional thermochemical facilities (e.g., grid furnace) is generally hindered by the high water content and intrinsic heterogeneity that makes it difficult to have reliable plant operation. Liquid refuse-streams are often characterized by small volumes and considerable spreading over the territory, especially in rural areas. Their treatment in relatively small plants would avoid shipping to large facilities, e.g., biomass-fired power plants and waste incinerators, with benefits for the $\mathrm{CO}_{2}$ footprint. It would be desirable to devise fluidized bed treatments (combustion or gasification) that could simultaneously ensure de-odorization, reduction of volumes, destruction of pollutants and the recovery of their energy.

Table 3 summarizes the experimental and theoretical investigations on WASMIX conversion in a fluidized bed, also including the cases of coal (C-WASMIX) or biomass (B-WASMIX) addition to the slurry.

Caprolactam tails, a slurry waste produced in the synthesis of caprolactam, were incinerated in a lab-scale FB plant [59]. The high water (65\% wt.) and ash (25\% wt.) contents required external heating, accomplished by an electric furnace. The bed temperature was kept at a relatively low level $\left(500\right.$ and $\left.600{ }^{\circ} \mathrm{C}\right)$, giving rise to an accumulation of bed carbon that was periodically burnt by switching to oxidizing conditions. This pioneering research demonstrated advantages (mixing and heat transfer) and limits (carbon and ash accumulation) of FB incineration for a difficult slurry waste.

Acid tar wastes from oil refining with a water content of about $69 \%$ wt. and an ash content of $2.6 \% \mathrm{wt}$. were incinerated in a pilot FB plant operated with limestone addition for $\mathrm{SO}_{2}$ removal at an optimal temperature of $850{ }^{\circ} \mathrm{C}$ [60]. Coal was also added separately for sustaining the bed temperature. The combustion efficiency was high (around 
$99 \%$ ), whereas average $\mathrm{SO}_{2}$ emission-levels (in the flue gas) of around $400 \mathrm{ppm}$ at $4 \% \mathrm{O}_{2}$ (vol.) were achieved, thus complying with the former limits on emissions. Difficulties were experienced in limiting $\mathrm{SO}_{2}$ fluctuations as a consequence of some unreliability in limestone feeding.

Table 3. Investigations on waste derived mixtures in a fluidized bed.

\begin{tabular}{|c|c|c|c|c|c|}
\hline Internal Size, $\mathrm{mm}$ & Slurry Fuel & Feeding Point & Pressure & Process & Ref. \\
\hline $40^{1}$ & WASMIX & submerged & atmospheric & combustion & [59] \\
\hline 20 & WASMIX & submerged & atmospheric & gasification & [61] \\
\hline $600 \times 600^{2}$ & WASMIX & submerged & atmospheric & combustion & [25] \\
\hline $1200 \times 1200^{2}$ & WASMIX & submerged & atmospheric & combustion & [60] \\
\hline n.a. & C-WASMIX & submerged & atmospheric & combustion & [62] \\
\hline $370^{1}$ & C-WASMIX & submerged & atmospheric & combustion & [63] \\
\hline $3050 \times 3050^{2}$ & C-WASMIX & submerged & $1.5 \mathrm{MPa}$ & combustion & {$[64]$} \\
\hline $230 \times 230^{2}$ & C-WASMIX & submerged & atmospheric & combustion & [65] \\
\hline $110^{1}$ & C-WASMIX & overbed & atmospheric & combustion & [66] \\
\hline $140^{1}$ & C-WASMIX & submerged & atmospheric & gasification & [67] \\
\hline $300 \times 300^{2}$ & B-WASMIX & submerged & atmospheric & combustion & [68] \\
\hline $9000^{1}$ & B-WASMIX $\S$ & submerged & $2.2 \mathrm{MPa}$ & gasification & [26] \\
\hline $9000^{1}$ & B-WASMIX § & submerged & 4.1 $\mathrm{MPa}$ & gasification & [69] \\
\hline
\end{tabular}

${ }^{1}$ Circular geometry; ${ }^{2}$ Square/rectangular geometry, ${ }^{\S}$ modelling.

\subsection{Waste Derived Mixtures with Coal Addition (C-WASMIX)}

Coal-based mixtures (C-WASMIX) can be obtained by addition of pulverized coal to liquid refuse-streams in order to increase the heating value and sustain incineration/combustion. Generally, the calorific value of the raw effluent is very low and, as a consequence, cocombustion is required. For ease of preparation and for direct use on site, the idea of turning such liquid streams into mixtures with coal seems attractive. Contrary to the case of CWM conceived for spray burners, sophisticated rheological properties are not required for FB feeding, and mixtures should be similar in consistency and stability to coal-water pastes, having coal particle size up to few millimeters and optimized pseudo-viscosity [55].

Bonfitto et al. [38] proposed such an approach for agro-industrial effluents in order to have an environmentally-compatible disposal with energy recovery by co-firing with coal. They reported tests of thermal treatment in a pilot $\left(1 \mathrm{MW}_{\mathrm{t}}\right) \mathrm{FB}$ plant designed for the combustion of RDF or biomass [62]. Olive mill waste waters and sludge from wine distillation were used. The addition of the slurry in the dense phase region of the bed did not significantly modify the performance of the plant. The combustion efficiency was greater than $99 \%$, but the presence of alkali in the ash of the fuel gave rise to some fouling and slagging problems. The investigators proposed in the same paper a process for combined production of heat and power from the thermo-chemical disposal of agricultural liquid streams. This would result in useful energy conversion, even in plants with limited capacity.

Following the idea proposed by Bonfitto et al. [38], an experimental campaign at a semi-pilot-scale (200 kWt) was carried out in bubbling FB [63] with a slurry formed by a concentrated distillery sludge and sub-bituminous coal. The mixture was prepared on site by adding to the distillery sludge coal particles with an average size of $0.22 \mathrm{~mm}$, upon mechanical stirring with the agro-industrial sludge. The obtained mixture was stable for hours and was fed to the FB combustor by means of a volumetric, low-speed pump. The fuel was smoothly burnt at a temperature of $850^{\circ} \mathrm{C}$, though the water content of the mixture achieved was up to $64 \%$ by mass. The combustion efficiency achieved was up to $99.4 \%$, with an appreciable conversion of unburned species (CO and C fines) in the freeboard and cyclone. The combustion performance was also dependent on the dispersing air velocity at the slurry inlet, leading to higher $\mathrm{CO}$ emission and lower combustion efficiency, because of a larger formation rate of carbon fines. Similarly to CWM combustion, 
formation of both carbon deposits and aggregates are beneficial for the FB combustion mechanism as they ensure an improved residence time in the chamber. In the same study [63] a theoretical approach was proposed in order to estimate the size of the slurry droplet, detaching from the injection nozzle in the absence of dispersing air. Theoretical results were in good agreement with experimental trends, obtained in bench-scale tests and aimed at determining the yields of carbon phases generated by slurry injection under inert atmosphere and hot conditions.

North and Eleftheriades [64] presented the results of co-firing coal and coffee ground sludge with water at $87 \%$ wt. After preliminary tests at a small scale, they successfully used a large-scale FB boiler operated at $1.5 \mathrm{MPa}$ for the sludge incineration, even if the most difficult aspect of their trials was the sludge feeding, because of the tendency to form a cake inside the pumping device. They also derived a thermal balance over the small-scale unit in order to evaluate the optimal water loss in the freeboard from the falling sludge, upon over-bed feeding. Therefore, the residence time of the sludge in the freeboard before the contact with the bed was fixed at a value that prevented the excessive cooling of the gas leaving the bed.

C-WASMIX was produced upon mixing CWM with printing and dyeing sewage sludge at different ratios. The resulting slurry was incinerated in a semi-pilot circulating fluidized bed $(\mathrm{CFB})(230 \times 230 \mathrm{~mm})$ under atmospheric pressure [65]. At an operating temperature of $1000{ }^{\circ} \mathrm{C}$, the concentrations of pollutants were well below the emission standard. The operation was optimal when the sludge content was between $20 \%$ and $30 \%$ wt. Recently, the comparison between combustion characteristics of CWM and lignite washery tails (a waste stream from lignite preparation) was obtained in a bench-scale CFB combustor (36 kWth) [66]. The authors reported similar combustion characteristics in terms of efficiency and emissions, complying with European and Chinese standards. However, the thermal response was worsened when washery tails were used with respect to CWM, giving a reduced temperature profile along the vertical axis that suggest the need for optimization of air staging and plant design.

The air gasification of a slurry at equivalence ratio 0.5 produced by mixing wet olive husks, pulverized coal and small amount of rape-seed oil was investigated by Ruoppolo et al. [67] in a lab-scale bubbling FB gasifier, equipped with a conical distributor. The coal and water contents in the slurry were 18 and 70\% wt., respectively. Although the test rig was electrically heated at $800^{\circ} \mathrm{C}$, some useful insights were obtained: reliable feeding of the gasifier, steady generation of syngas with total concentration of combustible species up to $20 \%$ vol., and relatively high tar yield due to the presence of the rape-seed oil. In a further study [70], a similar slurry was gasified in an inert and catalytic bed, obtaining substantially high improvement of tar conversion, even if the gasification efficiency remained below $30 \%$. The low coal reactivity and the limited bed temperature $\left(830^{\circ} \mathrm{C}\right)$ were indicated as the major causes of carbon fine elutriation and loss, with drawbacks in gasification efficiency.

\subsection{Waste-Derived Mixture with Biomass Addition (B-WASMIX)}

Biomass-based mixtures (B-WASMIX) are made of watery industrial wastes (e.g., wet tomato skin and seeds) or can be obtained by addition of biogenic solids (e.g., sawdust, crushed nutshell, and olive husks) to liquid refuse-streams.

The FB incineration of an agro-industrial sludge was investigated by Miccio et al. [25] in a demonstration plant ( $500 \mathrm{~kW}$ th bubbling FB combustor with square section of $0.4 \times 0.4 \mathrm{~m}$ ). This plant was erected and installed inside an olive-oil mill for burning a concentrated liquid stream (i.e., wet olive husks) as waste after oil extraction. In this investigation, no addition of auxiliary fuel (coal or biomass) was done, the water content of olive husks being about $65 \%$ wt. The plant operation was reliable and efficient at a bed temperature between 800 and $850{ }^{\circ} \mathrm{C}$ and an excess air ratio $1.3 \pm 0.1$. The temperature increase in the freeboard was very limited $\left(10-20^{\circ} \mathrm{C}\right)$, confirming the high efficiency of the bed region to convert the fuel. Only NOx emission was critical, owing to the high nitrogen content in olive husks. Thanks to the large plant size, standard equipment of the olive-oil factory, 
such as pumps, kneads, hoppers, and tanks were directly connected to the FB incinerator, providing benefits for process intensification. Although the plant was not equipped with exchangers, the heat recovery from hot flue-gases, exiting at same temperature as the bed, would provide large heat for steam generation to be used in the olive-oil factory.

A sludge from biodiesel production, very rich in lignin, was tested in a semi-pilot combustor after mixing with rape-seed oil, for improving the heating value of the feedstock [68]. The obtained emulsion, having a sludge/oil/water composition of 60/16/24\% on a mass basis and a total water content of $63 \%$ wt., resulted stable for more than 30 days, even in the absence of emulsifiers. A rheological characterization proved it to be a pseudoplastic behavior with viscosity approaching that of rape-seed at high shear stress. In any case, the sludge was effectively managed by means of an industrial peristaltic pump. The combustion tests at temperature of about $830{ }^{\circ} \mathrm{C}$ and excess air ratio $1.3 \pm 0.1$ showed that the carbon loss at the cyclone was very low, and the combustion efficiency was higher than $99.5 \%$. A temperature increase up to $80{ }^{\circ} \mathrm{C}$ was experienced in the freeboard as a consequence of vapor and volatile matter combustion as in the case of solid biomass fuels [71]. It is worth noting that the normalized NO concentration was compliant with the Italian regulation for biomass combustion plants; also, no agglomeration phenomena of bed materials were detected.

Raw glycerol, a residue of biodiesel production, represents around $10 \%$ of the whole process stream and its purification is quite expensive. Therefore, its utilization has been proposed as an improvement on the alternatives based on solid fuel-water slurries; i.e., glycerol can be used as the liquid media or part of that media in slurry fuels instead of water [26]. Experiments of glycerol gasification were carried out in a lab-scale FB plant in an alumina bed at temperatures of $700-900{ }^{\circ} \mathrm{C}$ under an $\mathrm{N}_{2} / \mathrm{O}_{2}$ atmosphere [61]. Glycerol waste gasification resulted in less char formation when compared with other biomass and a heating value of product gas from $0.8-4.9 \mathrm{MJ} / \mathrm{m}^{3}$ was obtained. In this framework, de Souza-Santos et al. [26] theoretically studied the co-gasification of raw glycerol and biomass (sugar cane bagasse, SCB) slurries for power generation. Two different configurations have been investigated: in configuration A, SCB, leaving the mill with approximately 50\% moisture, is preliminarily dried in a fluidized bed atmospheric dryer, and then mixed with glycerol and pumped into a pressurized bubbling fluidized bed gasifier; in configuration B, wet SCB is directly mixed with raw glycerol to form a slurry, which is then directly injected into the pressurized bubbling fluidized bed gasifier. In both cases, gasification takes place at $2 \mathrm{MPa}$ and it is coupled with a Rankine cycle to produced steam at $10 \mathrm{MPa}$. An overall 1st Law efficiency of about $43 \%$ and $41.5 \%$ has been achieved in configurations $\mathrm{A}$ and $B$, respectively, which are remarkably higher than the $20 \%$ achieved at existing power generation units consuming SCB [69]. Nevertheless, in spite of a slightly lower efficiency, configuration $\mathrm{B}$ may be more attractive since it does not require the preliminary drying stage and involves a lower consumption of glycerol, which can be very significant since it is preferable for sugar-alcohol mills to employ lower amounts of other feedstock than SCB into their processes of power generation. The study of power generation consuming SCBglycerol slurries has been deepened: increasing the gasification pressure from 2 to $4 \mathrm{MPa}$ in combination with variations of glycerol injection rates makes it possible to enhance the theoretical efficiency up to about $46 \%$ [72].

\section{Discussion and Perspectives}

Most of the reported studies on slurry fuels have been carried out in bubbling fluidized beds (BFB) and, hence, no deductions can be directly made on the comparison with CFB options. Nevertheless, on the basis of the fundamental studies on jets in fluidized beds, the presence of a dense phase, as in the case of BFB, speeds up the evaporation of the water and promotes the formation of carbon condensed phases [49]. Conversely, an CFB alternative would be more effective for the different hydrodynamics of the riser [73], with limited back-mixing and enhanced heat transfer [74]. An alternative could be given by fluidized beds with an innovative design of the distributor and the presence of internals that favor 
both bed mixing/circulation and transport phenomena. In this respect internal circulating FBs [75] or spouted/jet fountain configurations [76] are expected to couple advantages of both BFB and CFB.

The most relevant operating conditions of combustion and gasification are temperature and excess air ratio (equivalence ratio for gasification) [5]. The reviewed literature showed that the effect of bed temperature, always in the range $800-900{ }^{\circ} \mathrm{C}$, was as expected: the higher the process temperature, the better the performance of the combustor/gasifier. The excess air ratio or equivalence ratio were kept at typical values for FB combustion $(1.10-1.30)$ or gasification $(0.30-0.50)$. It is worth recalling that the choice of these variables should be a compromise between better plant performance (emissions, efficiency, carbon conversion, and syngas quality) and power/heat requests for the fluidization stream.

Figure 2 displays the graphical distribution of the reviewed investigations per each slurry fuel, denoting the predominance of research and industrial activities on coal-based mixtures (CWM, CWP, C-WAM, C-WASMIX, and COS), accounting for about 75\%. CWM and C-WASMIX, representing an easy process option, have the highest value (25\%). Biomass-based slurries (WASMIX, B-WASMIX) are equally distributed.

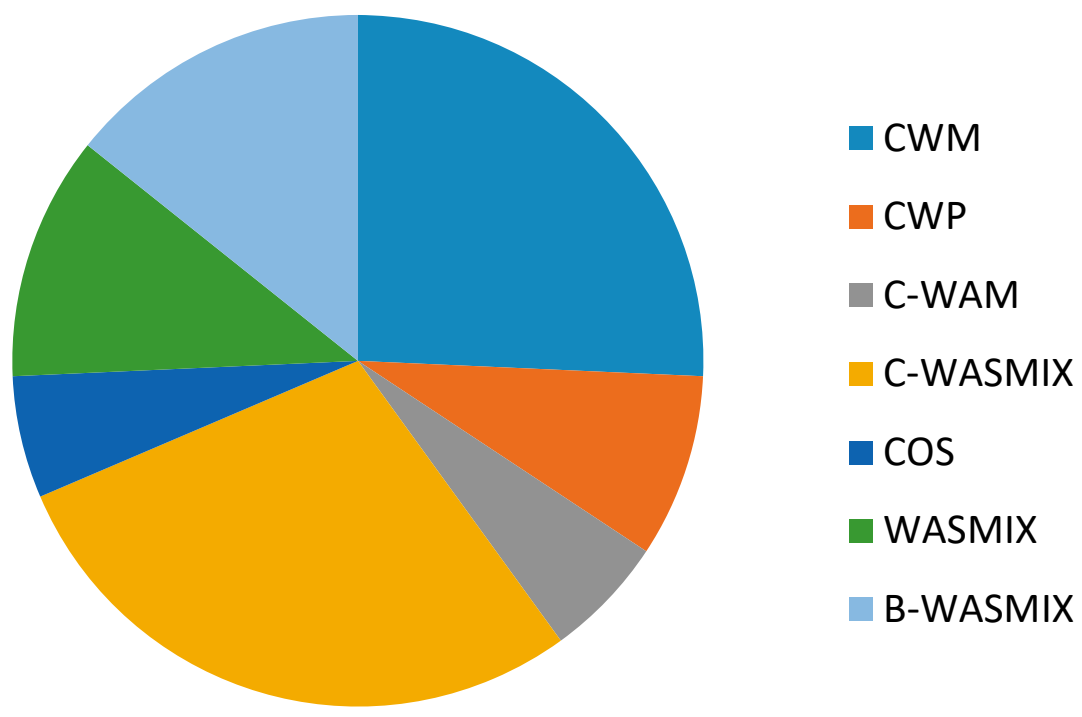

Figure 2. Distribution of slurry fuels used in the reviewed investigations.

Figure 3 shows the cumulative trend along the last four decades of the reviewed investigations, also including the distinction between three different cases of (i) coalbased mixtures; (ii) coal-biomass-based mixtures; and (iii) biomass-based mixtures. In the decades between 1980 and 2000, most of the investigations were devoted to the use of coal-based mixtures. The situation reversed after 2000 with a growing interest in the use of biomass-based slurries and a rapid growth in the last decade of the curve relating to biomass alone.

As shown in Figure 3, the research and the commercial applications of FB combustion of coal-based mixtures and pastes date back $20-30$ years. That was a historical period in which a strong push, either political, financial, or scientific, was enacted to support and expand coal utilization in the energy sector, likely with a higher energy conversion efficiency and with a reduced generation of pollutants (in atmosphere, surface water, and soil) as enabled by the adoption of new technologies. To date, this is not true any longer; actually, it is well known that coal-based technologies are subject to stricter and stricter regulatory issues or even a ban due to climate change constraints and roadmaps. 


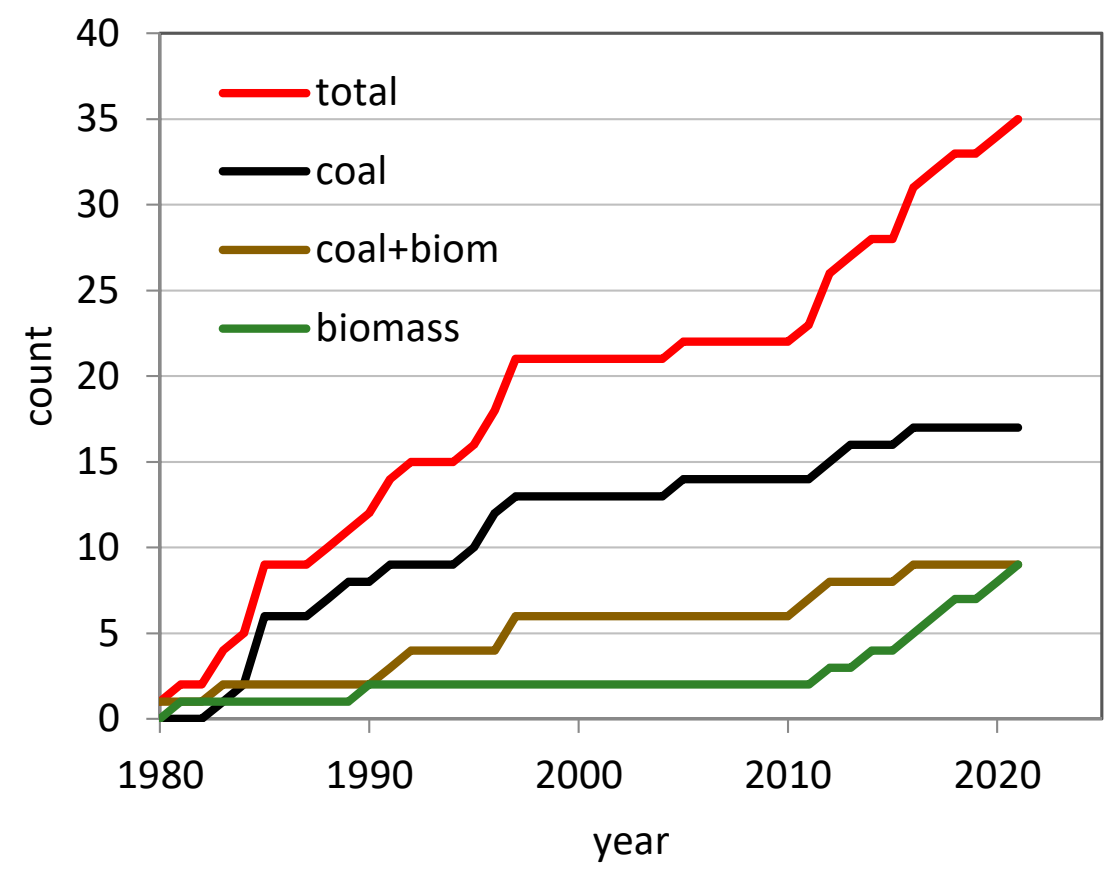

Figure 3. Evolution along the time of investigations on slurry fuels.

In any case, the results of research investigations and the experience gained after commercial applications of FBC to coal-based mixtures and pastes remain of interest: much of the scientific understanding (e.g., the interaction of wet feed with the hot bed) and many of the technological and engineering solutions (e.g., pumping and feeding slurries and compacting and operating plant components sealed in a pressure vessel) have already been or will be transferred to other process cases dealing with watery feedstocks and wet slurry feed (e.g., biomass-based).

Furthermore, biomass-based watery mixtures circumvent some problems posed using solid biomass directly as a feedstock. For instance, with reference to the handling and feeding section of biomass to the thermal conversion plant, some important technological challenges arise: fiber-rich solid biomass impairs rotating valves due to the interlacing of fibers of neighboring particles inside the hopper [26]; humid biomass feedstocks undergo fermentation and putrefaction; dry biomass inside the storage or feeding hoppers may be subjected to pyrolysis or even self-combustion [77], and hence require a non-oxidizing atmosphere and injection of a cooling inert gas. All of the above problems can be overcome when the solid biomass is mixed with a liquid, even a refuse-stream, and additives to form a slurry or a suspension, which can be easily stored or pumped into the vessel.

It is also worth noting that using biomass slurries instead of dry biomass/waste granules in BFB plants can limit the occurrence of dynamic [78] and segregation phenomena [79], as well as bed bypass to the freeboard due to the fast release of volatiles from fuel particles [80].

In contrast to coal-based slurries and pastes, biomass-based mixtures, regardless of the biogenic liquid and solid component, are "renewable" by definition. Therefore, they have the potential of exploiting bio-resources in the sustainable production of heat and power. This is a crucial point in the framework of the ongoing transition [81] to technologies that are considered to be resource-saving for a circular economy and environmentally friendly for zeroing of emissions and global warming control. This desirable transition is qualitatively shown in Figure 4, where the paradigm shift of the circular approach is implemented by replacing coal with biomass. In this respect, new challenges and, hence, new research investigations will arise from the need of coping with different material properties in formulating the waste-derived mixture with biomass addition: (i) the hydrophilic behavior of biomass with respect to the hydrophobic coal; (ii) the lower heating value of biomass; 
(iii) the fibrous structure; and (iv) the lower grindability, the tendency to degrade in presence of water; etc. (Figure 4).

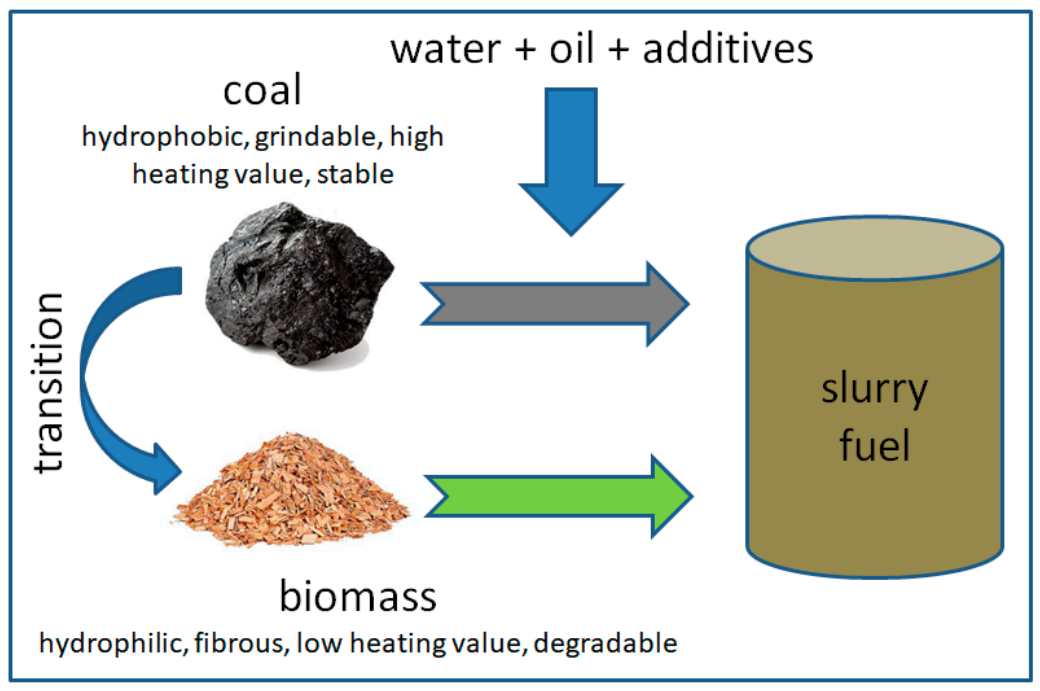

Figure 4. Transition from coal-based to biomass-based slurry fuels.

Finally, the transition to biomass for this class of fuels will likely lead to phasing out large plants, especially the pressurized ones, so the typical scale for applications with slurry fuels will fall between 0.5 and $50 \mathrm{MW}_{\mathrm{t}}$, in both bubbling and circulating FB options. Slurries with high water content will be preferably processed in bubbling FBs, having high thermal inertia. Gasification/pyrolysis will be better carried out in CFBs, owing to the limited back-mixing of this system and the possibility of implementing a dual process with generation of more energetic products [82].

Author Contributions: Data collection, F.M., F.O. and F.R.; Writing—original draft preparation, F.M., P.A. and M.M.; writing-review and editing, F.M., F.R. and M.M.; Formal analysis, all; Graphics, F.R. and F.M.; All authors have read and agreed to the published version of the manuscript.

Funding: This research received no external funding.

Institutional Review Board Statement: Not applicable.

Informed Consent Statement: Not applicable.

Data Availability Statement: This review has been based on published literature data that are accessible under open or restricted terms. Figures and tables are produced specifically for the scope of the review.

Conflicts of Interest: The authors declare no conflict of interest.

\section{References}

1. Leckner, B. Developments in fluidized bed conversion of solid fuels. Therm. Sci. 2016, 20, S1-S18. [CrossRef]

2. Blaszczuk, A.; Nowak, W. Bed-to-wall heat transfer coefficient in a supercritical CFB boiler at different bed particle sizes. Int. J. Heat Mass Transf. 2014, 79, 736-749. [CrossRef]

3. Kunii, D.; Levenspiel, O. Chapter 2-Industrial Applications of Fluidized Beds. In Fluidization Engineering, 2nd ed.; Kunii, D., Levenspiel, O., Eds.; Butterworth-Heinemann: Oxford, UK, 1991; pp. 15-59.

4. Di Natale, F.; Nigro, R.; Scala, F. 5-Heat and mass transfer in fluidized bed combustion and gasification systems. In Fluidized Bed Technologies for Near-Zero Emission Combustion and Gasification; Scala, F., Ed.; Woodhead Publishing: Sawston, UK, 2013; pp. 177-253.

5. Basu, P. Combustion and Gasification in Fluidized Beds, 1st ed.; CRC Press: Boca Raton, FL, USA, 2006.

6. Anthony, E.J. Fluidized bed combustion of alternative solid fuels; status, successes and problems of the technology. Prog. Energy Combust. Sci. 1995, 21, 239-268. [CrossRef]

7. Trinks, W.; Mawhinney, M.H.; Shannon, R.A.; Reed, R.J.; Garvey, J.R. Industrial Furnaces; John Wiley \& Sons, Inc.: Hoboken, NJ, USA, 2004; Chapter 4. 
8. Walas, S.M. Chemical reactors. In Perry's Chemical Engineers' Handbook, 7nd ed.; Perry, R.H., Green, D.W., Maloney, J.O., Eds.; McGraw-Hill: New York, NY, USA, 1997.

9. Massimilla, L.J.; Johnstone, H.F. Reaction kinetics in fluidized beds. Chem. Eng. Sci. 1961, 16, 105-112. [CrossRef]

10. Anthony, E.J.; Granatstein, D.L. Sulfation phenomena in fluidized bed combustion systems. Prog. Energy Combust. Sci. 2001, 27, 215-236. [CrossRef]

11. Liu, Y.; Peng, J.; Kansha, Y.; Ishizuka, M.; Tsutsumi, A.; Jia, D.; Bi, X.T.; Lim, C.J.; Sokhansanj, S. Novel fluidized bed dryer for biomass drying. Fuel Process. Technol. 2014, 122, 170-175. [CrossRef]

12. Iannello, S.; Morrin, S.; Materazzi, M. Fluidised Bed Reactors for the Thermochemical Conversion of Biomass and Waste. KONA Powder Part. J. 2020, 37, 114-131. [CrossRef]

13. Yang, W.C. Bubbling fluidized beds. In Handbook of Fluidization and Fluid-Particle Systems; Yang, W.C., Ed.; Marcel Deccer Inc.: New York, NY, USA, 2003.

14. Chirone, R.; Miccio, F.; Scala, F. On the Relevance of Axial and Transversal Fuel Segregation during the FB Combustion of a Biomass. Energy Fuels 2004, 18, 1108-1117. [CrossRef]

15. Gómez-Barea, A.; Leckner, B. Modeling of biomass gasification in fluidized bed. Prog. Energy Combust. Sci. 2010, 36, 444-509. [CrossRef]

16. Puig-Arnavat, M.; Bruno, J.C.; Coronas, A. Review and analysis of biomass gasification models. Renew. Sustain. Energy Rev. 2010, 14, 2841-2851. [CrossRef]

17. Shimizu, T. 15-Pressurized fluidized bed combustion (PFBC). In Fluidized Bed Technologies for Near-Zero Emission Combustion and Gasification; Scala, F., Ed.; Woodhead Publishing: Sawston, UK, 2013; pp. 669-700.

18. Williams, A. Chapter 7-Combustion of two-phase fuels. In Combustion of Liquid Fuel Sprays; Williams, A., Ed.; ButterworthHeinemann: Oxford, UK, 1990; pp. 161-185.

19. McHale, E.T. Coal-water fuel combustion. In Symposium (International) on Combustion; Elsevier: Amsterdam, The Netherlands, 1986; Volume 21, pp. 159-171.

20. Nunes, L.J.R. Potential of Coal-Water Slurries as an Alternative Fuel Source during the Transition Period for the Decarbonization of Energy Production: A Review. Applied Sciences 2020, 10, 2470. [CrossRef]

21. Antonini, G.; Francois, O. A new way to handle pulverized coal: The pumpable coal/water/air mixtures (C-WAM). In Proceedings of the 7th International Symposium on Coal Slurry Fuels Preparation and Utilisation, New Orleans, LA, USA, $21-24$ May 1985.

22. Wardell, R.V. Solid preparation and handling. In Pressurized Fluidized Bed Combustion; Cuenca, M.A., Anthony, E.J., Eds.; Springer: Berlin/Heidelberg, Germany, 1995.

23. Priyadarsan, S.; Annamalai, K.; Sweeten, J.M.; Mukhtar, S.; Holtzapple, M.T. Fixed-bed gasification of feedlot manure and poultry litter biomass. Trans. ASAE 2004, 47, 1689-1696. [CrossRef]

24. Qian, X.; Lee, S.; Chandrasekaran, R.; Yang, Y.; Caballes, M.; Alamu, O.; Chen, G. Electricity Evaluation and Emission Characteristics of Poultry Litter Co-Combustion Process. Appl. Sci. 2019, 9, 4116. [CrossRef]

25. Miccio, F.; Ruoppolo, G.; Russo, S.; Urciuolo, M.; De Riccardis, A. Fluidized bed combustion of wet biomass fuel (olive husks). Chem. Eng. Trans. 2014, 37, 1-6.

26. De Souza-Santos, M.L. Proposals for power generation based on processes consuming biomass-glycerol slurries. Energy 2017, 120, 959-974. [CrossRef]

27. Okasha, F.M.; El-Emam, S.H.; Mostafa, H.K. The fluidized bed combustion of a heavy liquid fuel. Exp. Thermal Fluid Sci. 2003, 27, 473-480. [CrossRef]

28. Okasha, F. Smooth combustion of gaseous fuels in a novel configuration of fluidized bed. Fuel 2013, 106, 512-518. [CrossRef]

29. Wang, F.; Yu, G.; Liu, H.; Li, W.; Guo, Q.; Xu, J.; Gong, Y.; Zhao, H.; Lu, H.; Shen, Z. Opposed multi-burner gasification technology: Recent process of fundamental research and industrial application. Chin. J. Chem. Eng. 2021, 35, 124-142. [CrossRef]

30. Mielke, K.; Kolb, T.; Müller, M. Chemical fractionation of inorganic constituents in entrained flow gasification of slurry from straw pyrolysis. Biomass Bioenergy 2020, 141, 105732. [CrossRef]

31. Ayol, A.; Tezer Yurdakos, O.; Gurgen, A. Investigation of municipal sludge gasification potential: Gasification characteristics of dried sludge in a pilot-scale downdraft fixed bed gasifier. Int. J. Hydrog. Energy 2019, 44, 17397-17410. [CrossRef]

32. Freda, C.; Cornacchia, G.; Romanelli, A.; Valerio, V.; Grieco, M. Sewage sludge gasification in a bench scale rotary kiln. Fuel 2018, 212, 88-94. [CrossRef]

33. Hupa, M. Ash-Related Issues in Fluidized-Bed Combustion of Biomasses: Recent Research Highlights. Energy Fuels 2012, 26, 4-14. [CrossRef]

34. Miccio, F.; Murri, A.N.; Medri, V.; Landi, E. Utilization of Fireclay for Preventing Fluidized-Bed Agglomeration during Biomass Thermochemical Processing. Ind. Eng. Chem. Res. 2019, 58, 23498-23507. [CrossRef]

35. Vodička, M.; Michaliková, K.; Hrdlička, J.; Hofbauer, C.; Winter, F.; Skopec, P.; Jeníková, J. External bed materials for the oxy-fuel combustion of biomass in a bubbling fluidized bed. J. Cleaner Prod. 2021, 321, 128882. [CrossRef]

36. Chirone, R.; Massimilla, L.; Salatino, P. Comminution of carbons in fluidized bed combustion. Prog. Energy Combust. Sci. 1991, 17, 297-326. [CrossRef]

37. Roberts, A.G.; Pillai, K.K.; Barker, S.N.; Carpenter, L.K. Combustion of 'Run-of-Mine' Coal and Coal-Water Mixtures in a Small PFBC. In Proceedings of the International Conference on Fluidized Bed Combustion, Philadelphia, PA, USA, 25-27 October 1982; pp. 482-489. 
38. Bonfitto, E.; Jacoboni, S.; Rossi, C.; Grazzini, G.C.; Frandi, R.; Marchini, G.; Brunetti, N. Combustion Technologies for a Clean Environment; Vilamoura, P., Carvalho, M.G., Eds.; CRC Press: Boca Raton, FL, USA, 1991; Volume 1, pp. 18-27.

39. Miccio, M.; Miccio, F. 8-Conversion of liquid and gaseous fuels in fluidized bed combustion and gasification. In Fluidized Bed Technologies for Near-Zero Emission Combustion and Gasification; Scala, F., Ed.; Woodhead Publishing: Sawston, UK, 2013; pp. 388-434.

40. La Nauze, R.D.; Duffy, G.J.; Potter, E.C.; Bradshaw, A.V. Fluidized Combustion of Coal Washery Wastes. In Fluidization; Grace, J.R., Ed.; Springer: Boston, MA, USA, 1980.

41. Trivett, G.S.; Field, R.S.; Mackay, G.D. Coal-limestone-water slurry testing in atmospheric fluidized-bed combustion. In Proceedings of the 6th International Symposium on Coal Slurry, Combustion and Technology, Orlando, FL, USA, 25 June 1984.

42. Trivett, G.S.; Field, R.S.; MacKay, G.D. C-coal-limestone-water slurry testing in atmospheric fluidized-bed combustion. In Proceedings of the Eighth International Conference on Fluidized-Bed Combustion, Houston, TX, USA, 18-21 March 1985; Volume 2, pp. 948-961.

43. Arena, U.; De Michele, G.; Maresca, A.; Massimilla, L.; Miccio, M. Fluidized combustion of coal and coal-water slurry: A comparison. In Proceedings of the Eighth International Conference on Fluidized-Bed Combustion, Houston, TX, USA, 18-21 March 1985; Volume 2, pp. 895-902.

44. Massimilla, L.; Miccio, M. The mechanism of combustion of a coal-water-slurry in a fluidized bed. Symp. Int. Combust. 1988, 21, 357-367. [CrossRef]

45. Hoy, R.; Scott, R.L.; Roberts, A.G. Operation of a small combustor on dry coal and on coal-water mixtures at pressures up to $20 \mathrm{~atm}$. In Proceedings of the Eighth International Conference on Fluidized-Bed Combustion, Houston, TX, USA, 18-21 March 1985; pp. 291-306.

46. Kefa, C.; Minghu, X.; Mingjiiang, N.; Xinyu, C.; Zhenfu, Y.; Guang, H.; Chongoing, L.; Deshou, L.; Yunsien, C. Fifth International Symposium on Coal Slurry Combustion, 1983; Volume 2, pp. 1092-1107. Available online: http://cn.shizueadachi.xyz/read/ ?id=-SJZAAAAYAAJ\&format=pdf\&server $=1$ (accessed on 10 November 2021).

47. Mei, J.S.; Cho, J.C.; Martin, D. In Proceedings of the 6th International Meeting on Coal-Liquid and Alternative Fuels, Halifax, NS, Canada, 13-17 October 1986. Available online: https://digital.library.unt.edu/ark:/67531/metadc710580/m2/1/high_res_d/67 7061.pdf (accessed on 10 November 2021).

48. Gregory, J.W.; Brown, R.C. Mechanisms of coal-water mixture combustion in fluidized beds. In Proceedings of the 10th International Conference on Fluidized Bed Combustion: FBC, Manaker, San Francisco, CA, USA, 30 April-3 May 1989.

49. Miccio, F.; Miccio, M.; Okasha, F. Formation rates of characteristic carbon phases during fuel-water slurry injection in a hot fluidized bed. Powder Technol. 1997, 91, 237-251. [CrossRef]

50. Anderson, J.; Jansson, S.A. Commissioning experience from three PFBC plants. In Proceedings of the International Conference on Fluidized Bed Combustion, Montreal, QC, Canada, 21-24 April 1991; pp. 787-793.

51. Svoboda, K.; Pohořelý, M.; Jeremiáš, M.; Kameníková, P.; Hartman, M.; Skoblja, S.; Šyc, M. Fluidized bed gasification of coal-oil and coal-water-oil slurries by oxygen-steam and oxygen-CO2 mixtures. Fuel Process. Technol. 2012, 95, 16-26. [CrossRef]

52. Antonini, G.; Gaporaud, M.B.; Brunello, J.M.; Grazzini, G.; Tonfoni, C.; Miccio, F.; Miccio, M. Efficiency of Combustion of a Specially Formulated Coal-Water Froth. In Proceedings of the 13th International Conference on Fluidized-Bed Combustion, Orlando, FL, USA, 7-10 May 1995; Volume 1, pp. 125-137.

53. Okasha, F.; Miccio, M. Prediction of coal-water slurry dispersion in a fluidized bed combustor. Symp. Combust. 1996, 26, 3277-3285. [CrossRef]

54. Massimilla, L. Gas jets in fluidized beds. In Fluidization, 2nd ed.; Davidson, J.F.C., Harrison, D., Eds.; Academic Press: London, UK, 1985; pp. 133-172.

55. Lu, P.; Zhang, M. Rheology of coal-water paste. Powder Technol. 2005, 150, 189-195. [CrossRef]

56. Jansson, S.A.; Veenhuizen, D.; Pillai, K.K.; Bjorklund, J. Coal-Fired PFBC Machine: Operating Experience and Further Development; American Society of Mechanical Engineers (Paper): New York, NY, USA, 1996; pp. 1-5.

57. Glushkov, D.O.; Lyrshchikov, S.Y.; Shevyrev, S.A.; Strizhak, P.A. Burning Properties of Slurry Based on Coal and Oil Processing Waste. Energy Fuels 2016, 30, 3441-3450. [CrossRef]

58. Pinto, F.; André, R.N.; Lopes, H.; Franco, C.; Carolino, C.; Galhetas, M.; Miranda, M.; Gulyurtlu, I. Comparison of a pilot scale gasification installation performance when air or oxygen is used as gasification medium 2-Sulphur and nitrogen compounds abatement. Fuel 2012, 97, 770-782. [CrossRef]

59. Cammarota, A.; D'Amore, M.; Donsì, G.; Massimilla, L. Fluidized bed incineration of a slurry waste from caprolactam production. Symp. Combust. 1981, 18, 257-264. [CrossRef]

60. Kerr, K.; Probert, S.D. Fluidised-bed incineration of acid tar wastes. Appl. Energy 1990, 35, 189-243. [CrossRef]

61. Sricharoenchaikul, V.; Atong, D. Fluidized Bed Gasification of Glycerol Waste for Generation of Fuel Products. J. Biobased Mater. Bioenergy 2012, 6, 643-649. [CrossRef]

62. Mariani, G.; Benfenati, E.; Fanelli, R.; Nicoli, A.; Bonfitto, E.; Jacopone, S. Incineration of agro-industrial wastes and macro- and micropollutants emission. Chemosphere 1992, 24, 1545-1551. [CrossRef]

63. Miccio, F.; Miccio, M. Dispersion and co-combustion studies for disposal of agro-industrial effluents in bubbling fluidized bed. In Proceedings of the 14th International Conference on Fluidized Bed Combustion, Vancouver, BC, Canada, 11-14 May 1997; pp. 1255-1266. 
64. North, B.C.; Eleftheriades, C.M. Incineration of a biomass sludge in a bubbling FBC. In Proceedings of the 14th International Conference on Fluidized Bed Combustion, Vancouver, BC, Canada, 11-14 May 1997.

65. Zhao, X.L.; Zhu, W. Emission Characteristicsof of PCBs of Combustion of Sludge-Coal Water Slurry in Fluidized Bed. Appl. Mech. Mater. 2013, 340, 382-387. [CrossRef]

66. Chen, D.; Yang, Q.; Jiang, X.; Lv, G.; Ma, Z.; Yan, J.; Cen, K.; Yu, X.; Liao, H.; Zhao, H. Comparison of Combustion and Emission Characteristics of an Indonesian Lignite Washery Tailing Slurry with a Bituminous Coal in a Bench-Scale Bubbling/Circulating Fluidized Bed Combustor. Energy Fuels 2016, 30, 10835-10846. [CrossRef]

67. Ruoppolo, G.; Cante, A.; Chirone, R.; Miccio, F.; Stanzione, V. Fluidized bed gasification of coal/biomass slurries. Chem. Eng. Trans. 2011, 24, 13-18.

68. Miccio, F.; Solimene, R.; Urciuolo, M.; Brachi, P.; Miccio, M. Fluidized bed combustion of a lignin-based slurry. Chem. Eng. Trans. 2016, 50, 271-276.

69. de Souza-Santos, M.L.; Camara, M.A. Theoretical Study on the Effect of Glycerol Fraction in Slurries with Biomass Consumed by a Power-Generation Process. Energy Fuels 2018, 32, 497-509. [CrossRef]

70. Ruoppolo, G.; Chirone, R.; Miccio, F.; Miccio, M.; Silvestri, N. On the mechanism of coal-biomass slurry fluidized bed gasification. In Proceedings of the 21st International FBC Conference, Napoli, Italy, 3-6 June 2012; pp. 789-796.

71. Miccio, F.; Scala, F.; Chirone, R. Fluidized Bed Combustion of a Biomass Fuel: Comparison between Pilot Scale Experiments and Model Simulations. J. Heat Transfer. 2005, 127, 117-122. [CrossRef]

72. Cadavez, C.C.; de Souza-Santos, M.L. Efficiency of a power generation alternative regarding the composition of feeding biomass-glycerol slurry; theoretical assessment. Energy 2021, 214, 118967. [CrossRef]

73. Davidson, J.F. Circulating fluidised bed hydrodynamics. Powder Technol. 2000, 113, 249-260. [CrossRef]

74. Grace, J.R.; Lim, C.J. 4-Properties of circulating fluidized beds (CFB) relevant to combustion and gasification systems. In Fluidized Bed Technologies for Near-Zero Emission Combustion and Gasification; Scala, F., Ed.; Woodhead Publishing: Sawston, UK, 2013; pp. 147-176.

75. Hosoda, S.; Kashima, N.; Sekikawa, S.; Toyoda, S.; Aoki, K.; Miyoshi, N. Status of pressurized internally circulating fluidized-bed gasifier (PICFG) development project. In Proceedings of the 15th International Conference on Fluidized Bed Combustion, Savannah, GA, USA, 16-19 May 1999.

76. Okasha, F.M. Short overview on the jetting-fountain fluidized bed (JFFB) combustor. Renew. Sustain. Energy Rev. 2016, 55, 674-686. [CrossRef]

77. Jones, J.M.; Saddawi, A.; Dooley, B.; Mitchell, E.J.S.; Werner, J.; Waldron, D.J.; Weatherstone, S.; Williams, A. Low temperature ignition of biomass. Fuel Process. Technol. 2015, 134, 372-377. [CrossRef]

78. Żukowski, W.; Jankowski, D.; Baron, J.; Wrona, J. Combustion dynamics of polymer wastes in a bubbling fluidized bed. J. Clean. Prod. 2021, 320, 128807. [CrossRef]

79. Niklasson, F.; Thunman, H.; Johnsson, F.; Leckner, B. Estimation of Solids Mixing in a Fluidized-Bed Combustor. Ind. Eng. Chem. Res. 2002, 41, 4663-4673. [CrossRef]

80. Yates, J.G.; MacGillivray, M.; Cheesman, D.J. Coal devolatilisation in fluidised bed combustors. Chem. Eng. Sci. 1980, 35, 2360-2361. [CrossRef]

81. Nyashina, G.S.; Kuznetsov, G.V.; Strizhak, P.A. Effects of plant additives on the concentration of sulfur and nitrogen oxides in the combustion products of coal-water slurries containing petrochemicals. Environ. Pollut. 2020, 258, 113682. [CrossRef]

82. Pröll, T.; Aichernig, C.; Rauch, R.; Hofbauer, H. Fluidized bed steam gasification of solid biomass-Performance characteristics of an 8 MWth combined heat and power plant. Int. J. Chem. Reactor Eng. 2007, 5, A54. [CrossRef] 